\title{
PENGARUH KEUNGGULAN BERSAING DI KAWASAN WISATA AIR PANAS TAMAN AIR SABDA ALAM HOTEL DAN RESORT CIPANAS KABUPATEN GARUT DALAM MENINGKATKAN KEPUTUSAN BERKUNJUNG
}

(Survei Terhadap Pengunjung di Kawasan Wisata Air Panas Taman Air Sabda Alam)

\author{
Pipit Fitriyani \\ Bagja Waluya \\ Manajemen Pemasaran Pariwisata FPIPS UPI
}

\begin{abstract}
ABSTRAK
Kabupaten Garut memiliki banyak potensi unggul untuk ditawarkan kepada wisatawan khususnya dalam bidang pariwisata. Salah satu potensi pariwisata di Kabupaten Garut adalah Cipanas Kecamatan Tarogong yang memiliki banyak atraksi wisata salah satunya adalah Kawasan Wisata Air Panas Taman Air Sabda Alam. Berdasarkan data kunjungan, pertumbuhan kunjungan di Taman Air Sabda Alam mengalami pertumbuhan yang paling kecil dibanding dengan pesaingnya pada tahun 2008-2009. Akan tetapi pada tahun 2009 ke 2010 Taman Air Sabda Alam berhasil meningkatkan jumlah kunjungan sebesar 8,6\%. Hal ini menunjukkan bahwa Taman Air Sabda Alam terus berusaha untuk meningkatkan jumlah kunjungan melalui berbagai strategi. Sehingga diharapkan Taman Air Sabda Alam untuk lebih meningkatkan eksistensinya dalam meningkatkan jumlah kunjungan. Salah satu upaya untuk meningkatkan dan mengembalikan jumlah kunjungan adalah dengan melaksanakan strategi keunggulan bersaing. Jenis penelitian ini adalah deskriptif dan verifikatif sehingga menggunakan metode explanatory survei. Teknik penarikan sampel yang digunakan adalah systematic sampling melalui pendekatan cross sectional method dan untuk teknik analisis data yang digunakan dalam penelitian ini adalah regresi linier berganda yaitu sampel yang diambil dari keseluruhan populasi sebanyak 100 pengunjung.Berdasarkan hipotesis penelitian, maka keunggulan bersaing memiliki pengaruh yang signifikan sebesar 59,2\% dalam upaya meningkatkan tingkat kunjungan.
\end{abstract}

Kata Kunci: Keunggulan Bersaing

\section{PENDAHULUAN}

1.1 Latar Belakang Penelitian

Pariwisata merupakan perdagangan jasa yang memiliki berbagai pengaturan yang kompleks karena mencakup pergerakan wisatawan dari daerah asalnya ke daerah tujuan wisata, hingga kembali ke daerah asalnya. Kegiatan pariwisata melibatkan berbagai komponen yang saling berkaitan; perusahaanperusahaan yang menghasilkan barang dan jasa secara keseluruhan atau sebagian untuk memenuhi kebutuhan para wisatawan selama berada jauh dari tempat tinggalnya (atraksi wisata, sarana akomodasi, transportasi, catering, travel agent, dan pelayanan lainnya), oleh karena itu industri pariwisata memegang peranan yang sangat penting dalam pengembangan pariwisata.

Pariwisata menurut Undang-undang Republik Indonesia Nomor 10 tahun 2009 tentang kepariwisataan adalah berbagai macam kegiatan wisata dan didukung berbagai fasilitas serta layanan yang disediakan oleh masyarakat, pengusaha, pemerintah, dan pemerintah daerah. Sedangkan yang dimaksud dengan wisatawan adalah orang yang melakukan wisata.

Industri pariwisata telah berkembang di berbagai negara, salah satunya adalah Indonesia yang memiliki daya tarik wisata yang unik baik alam ataupun buatan. Bentuk daya tarik wisata tersebut perlu dikenali dan kemudian dikembangkan untuk dapat menarik lebih banyak pengunjung. Saat ini sektor pariwisata dikembangkan menjadi andalan untuk mendatangkan devisa bagi Negara, peningkatan investasi, kesempatan berusaha, penyerapan tenaga kerja.

Wisnus dan wisman memiliki potensi yang besar dalam perkembangan pariwisata di Jawa Barat, hal ini dapat dilihat dari jumlah kunjungan wisman dan wisnus yang mengalami kenaikkan dan penurunan setiap tahunnya. Berikut ini adalah data statistik jumlah kunjungan wisman dan wisnus yang datang berkunjung ke daya tarik wisata di Jawa Barat dari tahun 2004 sampai dengan 2009. 
TABEL 1.1

DATA STATISTIK WISMAN DAN WISNUS KE JAWA BARAT

TAHUN $2004-2009$

\begin{tabular}{|l|l|c|c|}
\hline \multirow{2}{*}{ NO } & \multirow{2}{*}{$\begin{array}{l}\text { Nama Daya } \\
\text { Tarik Wisata }\end{array}$} & \multicolumn{2}{|c|}{ Jumlah } \\
\cline { 3 - 4 } & $\begin{array}{l}\text { Pemandian air } \\
\text { panas Cipanas }\end{array}$ & 311.252 & $\mathbf{2 0 1 0}$ \\
\hline 2 & Situ Bagendit & 180.717 & 201.571 \\
\hline 3 & Pantai Santolo & 153.400 & 165.482 \\
\hline 4 & $\begin{array}{l}\text { Pantai } \\
\text { Rancabuaya }\end{array}$ & 92.993 & 105.600 \\
\hline 5 & $\begin{array}{l}\text { Kawah } \\
\text { Papandayan }\end{array}$ & 51.577 & 56.288 \\
\hline 6 & $\begin{array}{l}\text { Golf Course } \\
\text { Flamboyan }\end{array}$ & 41.444 & 42.839 \\
\hline
\end{tabular}

Sumber : Disbudpar Jawa Barat Tahun 2010

Tabel 1.1 mengenai data statistik wisman dan wisnus yang berkunjung ke Jawa Barat dari tahun 2004 sampai dengan 2009. menjelaskan bahwa jumlah wisatawan mancanegara yang datang ke Jawa Barat yang mencapai jumlah paling sedikit adalah pada tahun 2005 sebanyak 207.935 orang dan tahun 2006 sebanyak 227.068 orang. Dimana di tahun 2005 sampai tahun 2006 Indonesia banyak mengalami bencana nasional seperti gempa bumi dan tsunami, sehingga dianggap tidak aman atau berbahaya untuk melakukan perjalanan wisata. Sehingga banyak negaranegara tetangga yang memberlakukan larangan kunjungan wisata ke Indonesia (travel warning) hingga kondisinya dinyatakan aman dan stabil.

Kabupaten Garut memiliki beraneka ragam daya tarik wisata, antara lain wisata alam, wisata budaya (wisata sejarah dan ziarah), wisata agro, dan wisata minat khusus. Hal ini menjadi pilihan pengunjung untuk berwisata ke Kabupaten Garut sebagai kawasan yang memiliki perkembangan pariwisata yang baik. Pentingnya posisi pengunjung dapat dilihat dari tingginya jumlah kunjungan yang mampu menggerakkan bisnis pariwisata khususnya dalam kondisi rendahnya pengunjung dari luar negeriUpaya pengembangan produk dan fasilitas wisata mampu meningkatkan tingkat kunjungan, dimana industri pariwisata secara terus menerus dibina untuk mampu bersaing baik melalui daya tarik pariwisata maupun produk yang diharapkan menjadi daya tarik bagi pengunjung. Berikut daya tarik wisata alam yang paling banyak dikunjungi tahun 2009-2010 di Kabupaten Garut.
TABEL 1.2

DAYA TARIK WISATA ALAM DI KABUPATEN GARUT TAHUN 2009-2010

\begin{tabular}{|c|r|c|}
\hline TAHUN & \multicolumn{1}{|c|}{ Wisman } & Wisnus \\
\hline $\mathbf{2 0 0 4}$ & 239.113 & 16.611 .680 \\
\hline $\mathbf{2 0 0 5}$ & 207.935 & 16.890 .316 \\
\hline $\mathbf{2 0 0 6}$ & 227.068 & 23.859 .547 \\
\hline $\mathbf{2 0 0 7}$ & 238.959 & 23.782 .302 \\
\hline $\mathbf{2 0 0 8}$ & 262.189 & 25.452 .040 \\
\hline $\mathbf{2 0 0 9}$ & 700.000 & 32.000 .000 \\
\hline
\end{tabular}

Sumber : DisParbud Kabupaten Garut, 2011

Tabel 1.2 dapat diketahui adanya persaingan di kawasan wisata di Kabupaten Garut. Setiap kawasan wisata memiliki karakteristik berbeda-beda dalam menentukan konsep kawasan wisatanya. Masing-masing kawasan wisata berusaha untuk meningkatkan dan mempertahankan jumlah kunjungan. Dilihat dari jumlah kunjungannya kawasan wisata pemandian air panas Cipanas menempati urutan pertama. Hal ini menunjukkan bahwa kawasan pemandian air panas Cipanas merupakan daya tarik wisata unggulan di Kabupaten Garut yang menjadi tujuan utama pengunjung untuk datang ke Kabupaten Garut.

Kawasan wisata pemandian air panas Cipanas berada di daerah Kecamatan Tarogong Kidul dengan suasana sejuk Gunung Guntur yang memiliki sumber mata air panas alami. Kawasan pemandian air panas Cipanas merupakan daya tarik wisata buatan dengan ruang lingkup taman rekreasi. Selain keindahan pemandangannya, kawasan pemandian air panas Cipanas merupakan salah satu daerah tujuan pariwisata yang harus memiliki keunikan tersendiri, seperti pemanfaatan produk lain, selain hanya penjualan kolam renangnya, juga penjualan kamar penginapannya sehingga mampu menarik minat pengunjung ke kawasan pemandian air panas Cipanas tersebut.

Kawasan wisata pemandian air panas Cipanas juga menawarkan berbagai daya tarik wisata seperti kolam renang, kolam berendam, taman rekreasi, pemandian, hotel, motel, jogging, refreshing, restoran, waterboom, meeting package dan lain-lain sehingga persaingan di kawasan ini semakin tinggi. Aktivitas yang dapat dilakukan di kawasan wisata ini adalah berenang, berendam, menikmati pemandangan dan berjalan-jalan di sekitar taman, berlibur, 
menginap dan menikmati suasana alam dari daya tarik wisata kawasan pemandian air panas Cipanas. Berikut jumlah kunjungan di kawasan wisata air panas Cipanas Garut yang menempati urutan empat tertinggi.

TABEL 1.3

JUMLAH KUNJUNGAN DI

KAWASAN WISATA AIR PANAS CIPANAS TAHUN 2008-2010

\begin{tabular}{|c|l|c|c|c|}
\hline N & PEMANDIAN & \multicolumn{3}{|c|}{ JUMLAH } \\
\cline { 3 - 5 } O & AIR PANAS & $\mathbf{2 0 0 8}$ & $\mathbf{2 0 0 9}$ & $\mathbf{2 0 1 0}$ \\
\hline 1 & $\begin{array}{l}\text { Kampung } \\
\text { Sumber Alam }\end{array}$ & 9,189 & 9,723 & 10,621 \\
\hline 2 & Danau Dariza & 7,889 & 8,250 & 9,510 \\
\hline 3 & $\begin{array}{l}\text { Taman Air } \\
\text { Sabda Alam }\end{array}$ & 8,110 & 7,980 & 8,674 \\
\hline 4 & Tirta Gangga & 5,490 & 6,900 & 7,692 \\
\hline
\end{tabular}

Sumber : Disparbud Kabupaten Garut, 2011

Tabel 1.3 menunjukkan tingkat kunjungan di kawasan pemandian air panas Cipanas dari tahun 2008 sampai 2010 yang menempati urutan empat tertinggi dari sekian banyak kawasan pemandian air panas. Dari data tersebut terlihat bahwa kawasan pemandian air panas yang mengalami pertumbuhan tertinggi yaitu Danau Dariza sebesar 15,27 \%. Hal ini membuktikan bahwa persaingan di kawasan wisata air panas Cipanas sangat tinggi. Sedangkan untuk pertumbuhan pengunjung terendah yaitu kawasan wisata air panas Taman Air Sabda Alam yang terjadi di tahun 2008 ke 2009 sebesar -1,6\%. Terjadinya penurunan kunjungan ini dikarenakan Taman Air Sabda Alam sedang melakukan perbaikan di beberapa fasilitasnya sehingga mengganggu kenyamanan pengunjung. Akan tetapi pada tahun 2009 ke 2010 Taman Air Sabda Alam berhasil meningkatkan jumlah kunjungan sebesar 8,6\%. Walaupun kenaikannya belum mencapai target yang diharapkan perusahaan, hal ini menunjukkan bahwa Taman Air Sabda Alam terus berusaha untuk meningkatkan jumlah kunjungan melalui berbagai strategi. Sehingga diharapkan Taman Air Sabda Alam untuk lebih meningkatkan eksistensinya dalam meningkatkan jumlah kunjungan.

Pihak Taman Air Sabda Alam pada bulan Juni 2011 mengubah nama dari Taman Air Sabda Alam Resort menjadi Taman Air Sabda Alam Hotel \& Resort. Hal ini bertujuan agar dapat lebih mengeksistensikan kawasan wisata Taman Air Sabda Alam untuk lebih berkesan di benak pengunjung. Manajemen Taman Air Sabda Alam melakukan berbagai strategi dalam meningkatkan jumlah kunjungan dengan segmentasi pengunjungnya adalah menengah keatas, bagi pengunjung yang menyukai permainan air dan menyukai berbagai produk wisata yang menantang. Salah satu strategi yang dilakukan Taman Air Sabda Alam Hotel \& Resort adalah strategi keunggulan bersaing (competitive advantage).

Strategi ini dilakukan untuk meningkatkan jumlah kunjungan yang berkunjung di kawasan wisata air panas Taman Air Sabda Alam dalam menawarkan produk dan jasanya, dengan memberikan pelayanan dan fasilitas terbaik yang berbeda dengan pesaingnya. Menurut Porter (2008:51)

"keunggulan bersaing berasal dari banyak aktivitas berlainan yang dilakukan oleh perusahaan dalam mendesain, memproduksi, memasarkan, menyampaikan, dan mendukung produknya. Masingmasing aktivitas ini dapat mendukung posisi biaya relatif perusahaan dan menciptakan dasar untuk diferensiasi."

Menurut Porter (2008:9) keunggulan bersaing tersebut meliputi strategi keunggulan biaya (cost leadership), strategi fokus (focus) dan strategi diferensiasi (differentiation). Berbagai strategi pemasaran yang dapat dilakukan oleh perusahaan terhadap keunggulan bersaing akan bergantung pada analisis lingkungan usaha untuk menentukan peluang dan ancaman. Pihak Taman Air Sabda Alam melakukan strategi keunggulan bersaing melalui keungulan biaya (cost leadership) dengan menciptakan biaya yang relatif dan diferensiasi (differentiation) dengan menciptakan keunikan dan keungguan produknya yang berbeda dengan pesaingnya. Sejalan dengan pernyataan di atas, Cravens (2003:26) mengemukakan bahwa:

"Perusahaan memperoleh keunggulan bersaing dengan memberikan nilai lebih kepada konsumen, melalui : (1) Harga yang lebih rendah dibandingkan para pesaing untuk manfaat yang sama, (2) Keunikan manfaat yang dapat menutupi harga yang tinggi." 
Strategi keunggulan biaya (Cost Leadership) yang dilakukan oleh pihak Taman Air Sabda Alam dengan mempertahankan harga yang ditawarkan kepada pengunjung, yaitu menawarkan harga yang relatif dibandingkan dengan pesaingnya. Hal ini dilakukan agar dapat menciptakan nilai bagi pengunjung, karena Taman Air Sabda Alam dianggap mampu memenuhi kebutuhan pengunjung dalam melakukan aktivitas wisata dengan harga yang murah dan fasilitas lengkap dibandingkan pesaingnya yang menawarkan atraksi wisata yang sama. Hal ini dimaksudkan untuk mendapatkan keuntungan yang lebih besar dari pesaing dan untuk memperoleh market-share yang lebih luas.

Taman Air Sabda Alam mampu mendesain proses produksi dengan efisien, seperti kolam air panas, wisata taman air, restoran, hotel dan bungalow, memiliki keahlian yang tinggi dalam industri karena learning/experience curve yang tinggi karena Taman Air Sabda Alam bediri saat wisata air panas sedang populer, dan belajar dari pesaing. Sejak saat itu pesaingnya bertambah banyak dan Taman Air Sabda Alam merupakan satu-satunya wisata air panas dengan konsep yang unik dan lengkap.

Differentiation strategy (strategi diferensiasi) yang dilakukan dengan menawarkan produk yang berbeda dari satu atau lebih para pesaing, melalui suatu cara atau banyak cara yang dapat dinilai oleh para pengunjung sehingga mempengaruhi pilihan pengunjung. Diferensiasi dilakukan untuk memenuhi harapan pengunjung dengan menciptakan produk-produk wisata yang unik dan berbeda dari satu atau lebih pesaing. Melalui suatu cara atau banyak cara yang dapat dinilai oleh para pengunjung, sehingga mempengaruhi pilihan pengunjung dalam menentukan kunjungan wisatanya dan dapat meningkatkan jumlah kunjungan. Seperti yang dikemukakan oleh Kotler dan Keller (2009:361), "diferensiasi adalah suatu tingkat ukuran dimana suatu merek dinilai berbeda dari pesaing."

Taman Air Sabda Alam mengembangkan produknya sehingga memiliki keunikan yang memberikan nilai tambah bagi pengunjung sehingga pengunjung berpersepsi bahwa produk yang ditawarkan memang berbeda dan lebih unik dari produk lain dalam industri pariwisata yang sejenis. Diferensiasi menciptakan persepsi pengunjung bahwa suatu produk dapat unggul daripada pesaing. Taman Air Sabda Alam dalam strategi diferensiasi membedakan destinasi dan produk pariwisata sehingga fokus dalam mengembangkan keunggulan yang komparatif pada bidang kepariwisataan. Taman Air Sabda Alam sebagai destinasi pariwisata mampu menjadi berbeda dengan pesaingnya karena menghasilkan aksesibilitas, atraksi dan amenitas yang unik dan berharga bagi pengunjung yang datang. Diferensiasi yang dilakukan oleh Taman Air Sabda Alam yaitu diferensiasi produk, diferensiasi pelayanan, diferensiasi personil, diferensiasi saluran pembelian, dan diferensiasi citra. Di mana kelima dimensi tersebut saling menguntungkan dalam produk utama yang ditawarkan oleh Taman Air Sabda Alam.

Strategi keunggulan bersaing yang dilakukan ini dapat memberikan dampak positif untuk perkembangan Kawasan Wisata Air Panas Taman Air Sabda Alam Garut dan diharapkan dapat memberikan kesadaran kepada pengunjung untuk datang berkunjung ke Taman Air Sabda Alam sehingga dapat meningkatkan tingkat berkunjung. Untuk mengetahui seberapa efektif kegiatan-kegiatan tersebut, maka perlu dilakukan penelitian dengan harapan strategi keunggulan bersaing yang dilakukan oleh Taman Air Sabda Alam telah sesuai dan dapat diterima bagi pengunjung khususnya dan bagi masyarakat umum. Berdasarkan uraian tersebut maka dirasakan perlu untuk melakukan penelitian tentang Pengaruh Keunggulan Bersaing Di Kawasan Wisata Air Panas Taman Air Sabda Alam Hotel dan Resort Cipanas Kabupaten Garut Dalam Meningkatkan Keputusan Berkunjung Pengunjung. (survei terhadap pengunjung di kawasan wisata air panas taman air sabda alam)

\subsection{Rumusan Masalah}

Berdasarkan hal-hal yang dibahas pada latar belakang penelitian, maka dapat dirumuskan masalah sebagai berikut :

1. Bagaimana Gambaran Keunggulan Bersaing di Kawasan Wisata Air Panas Taman Air Sabda Alam Cipanas.

2. Bagaimana Gambaran Keputusan Berkunjung Pengunjung di Kawasan Air Panas Taman Air Sabda Alam Cipanas.

3. Bagaimana Pengaruh Keunggulan Bersaing di Kawasan Wisata Air Panas Taman Air Sabda Alam Cipanas Di 
Kabupaten Garut Dalam Meningkatkan Keputusan Berkunjung.

\subsection{Tujuan Penelitian}

Berdasarkan rumusan masalah di atas, maka tujuan penelitian ini adalah untuk memperoleh hasil temuan mengenai :

1. Gambaran Keunggulan Bersaing di Kawasan Wisata Air Panas Taman Air Sabda Alam Cipanas.

2. Keputusan Berkunjung pengunjung di Kawasan Wisata Air Panas Taman Air Sabda Alam Cipanas.

3. Pengaruh Keunggulan Bersaing di Kawasan Wisata Air Panas Taman Air Sabda Alam Cipanas Di Kabupaten Garut Dalam Meningkatkan Keputusan Berkunjung.

\subsection{Kegunaan Penelitian}

1. Kegunaan Akademik (Teoritik)

Hasil penelitian ini diharapkan dapat memperluas dan mengembangkan kajian ilmu pemasaran pada daya tarik wisata, khususnya mengenai Pengaruh Keunggulan Bersaing dalam meningkatkan keputusan berkunjung, sehingga hasil penelitian ini dapat memberikan wawasan dan masukan bagi penulis dalam mengembangkan ilmu pemasaran pariwisata.

2. Kegunaan Praktis (Empirik)

Secara praktis hasil penelitian ini diharapkan dapat memberikan masukan bagi pihak Taman Air Sabda Alam Cipanas di Kabupaten Garut khususnya dalam upaya meningkatkan keputusan berkunjung pengunjung melalui pengaruh keunggulan bersaing, sehingga dapat menjadikan bahan informasi dalam upaya meningkatkan keputusan.

\section{KAJIAN PUSTAKA, KERANGKA PEMIKIRAN DAN HIPOTESIS}

\subsection{KAJIAN PUSTAKA}

\subsubsection{Konsep Pemasaran}

Pemasaran merupakan salah satu strategi yang dilakukan oleh seluruh industri jasa. Pemasaran adalah segala usaha yang meliputi penyaluran barang dan jasa dari sektor produksi ke sektor konsumsi. Menurut

American Marketing Association (AMA) tahun 2009 dalam Philip Kotler \& Kevin Lane Keller (2009:5) bahwa Pemasaran adalah suatu fungsi organisasi dan serangkaian proses untuk menciptakan, mengkomunikasikan, dan memberikan nilai bagi para pengunjung, dan untuk mengelola hubungan pengunjung dengan cara yang menguntungkan organisasi dan pemangku kepentingannya. Pemasaran berhubungan dengan mengidentifikasi dan memenuhi kebutuhan manusia dan masyarakat. Jasa sering dipandang sebagai suatu fenomena yang rumit. Kata 'jasa' (service) itu sendiri mempunyai banyak arti, mulai dari pelayanan pribadi (personal service) sampai jasa sebagai suatu produk. Jasa memiliki karakteristik yang berbeda dengan produk barang (fisik).

\subsubsection{Konsep Keunggulan Bersaing}

Dalam sebuah industri, pasti akan terjadi sebuah persaingan diantara perusahaan-perusahaan yang tergabung dalam industri tersebut. Persaingan menentukan ketetapan aktivitas perusahaan yang dapat menyokong kinerjanya, seperti inovasi, budaya kohesif atau pelaksanaan/implementasi yang baik. Menurut Mudrajab Kuncoro (2005:86), "Persaingan adalah keadaan ketika organisasi berperang atau berlomba untuk mencapai hasil atau tujuan yang diinginkan seperti konsumen, pangsa pasar, peringkat survei, atau sumber daya yang dibutuhkan. Sedangkan menurut Porter (2008:13) dalam keunggulan bersaing mengemukakan bahwa "Persaingan adalah inti dari keberhasilan atau kegagalan bersaing". Hal tersebut mengandung makna bahwa persaingan memiliki arti penting bagi sebuah perusahaan dalam menjalankan usahanya. Kegagalan atau keberhasilan suatu perusahaan tergantung pada keberaniannya untuk bersaing.

Menurut Porter (2008:13) Strategi bersaing adalah pencarian posisi bersaing yang menguntungkan di dalam suatu industri, dan merupakan arena yang fundamental tempat persaingan terjadi. Strategi bersaing bertujuan menegakkan posisi yang menguntungkan dan dapat dipertahankan terhadap kekuatan-kekuatan yang menentukan persaingan industri. keunggulan bersaing merupakan inti dari kinerja perusahaan di dalam pasar yang bersaing/kompetitif. Strategi ini berfokus pada peningkatan posisi bersaing produk dan jasa perusahaan dalam industri atau segmen pasar tertentu yang dilayani perusahaan. keunggulan bersaing harus berkembang dari pemahaman yang canggih akan aturan persaingan yang menentukan daya tarik 
suatu industri. Tujuan akhir strategi keunggulan bersaing adalah menanggulangi dan idealnya mengubah aturan itu demi kepentingan perusahaan.

Strategi bersaing tersebut merupakan bagian dari strategi bersaing generik (Porter,2008:9) yang meliputi strategi keunggulan biaya (cost leadership), strategi fokus (focus) dan strategi diferensiasi (differentiation). Ketiga unsur dari strategi generik tersebut terdiri dari dua jenis dasar keunggulan bersaing yaitu biaya rendah dan diferensiasi yang digabungkan dengan cakupan aktivitas yang berusaha dicapai yaitu strategi fokus (Porter:2008:15).

\subsubsection{Konsep Keputusan Berkunjung}

Tujuan dari kegiatan pemasaran adalah memuaskan kebutuhan (needs) dan keinginan (wants) pengunjung atau pengunjung sasaran. Oleh karena itu, pengunjung mempunyai arti yang penting bagi suatu perusahaan yaitu sebagai pengguna produk/jasa wisata. Pemahaman mengenai perilaku pengunjung ini meliputi bagaimana individu, kelompok dan organisasi, memilih, mengunjungi, menggunakan, dan tidak menggunakan barang dan jasa. Keputusan untuk berkunjung ke suatu tempat wisata (destinasi) mengambil asumsi dari teori keputusan pembelian. Keputusan untuk membeli timbul karena adanya penilaian yang objektif atau dorongan emosi. Berikut definisi mengenai keputusan pembelian yang diasumsikan sebagai keputusan berkunjung yang dikemukakan oleh beberapa ahli.

TABEL 2.1

DEFINISI KEPUTUSAN BERKUNJUNG MENURUT BEBERAPA AHLI

\begin{tabular}{|c|l|l|}
\hline No. & \multicolumn{1}{|c|}{ Ahli } & \multicolumn{1}{|c|}{ Definisi } \\
\hline 1. & $\begin{array}{l}\text { Kotler \& \& } \\
\text { Keller } \\
(2008: 240)\end{array}$ & $\begin{array}{l}\text { Tahap dam } \\
\text { pengambilan keputusan } \\
\text { di mana pengunjung } \\
\text { benar-benar } \\
\text { menggunakan } \\
\text { produk/jasa wisata. }\end{array}$ \\
\hline 2. & $\begin{array}{l}\text { Schiffman } \\
\text { dan Kanuk } \\
(2007: 625)\end{array}$ & $\begin{array}{l}\text { A decision is a } \\
\text { selection on action } \\
\text { from two or more } \\
\text { alternative choice. } \\
\text { Artinya, apabila } \\
\text { seseorang mengambil } \\
\text { keputusan, maka }\end{array}$ \\
\hline
\end{tabular}

\begin{tabular}{|c|c|l|}
\hline No. & Ahli & \multicolumn{1}{c|}{ Definisi } \\
\hline & & $\begin{array}{l}\text { terdapat beberapa } \\
\text { alternatif seperti dalam } \\
\text { melakukan pembelian. }\end{array}$ \\
\hline
\end{tabular}

Sumber: Pengolahan dari berbagai literatur

Berdasarkan pendapat dari beberapa ahli di atas bahwa keputusan berkunjung merupakan proses keputusan di mana pengunjung benar-benar memutuskan untuk menggunakan salah satu produk/jasa wisata diantara berbagai macam alternatif pilihan.

\subsubsection{Proses Pengambilan Keputusan Berkunjung}

Proses kunjungan dimulai jauh sebelum tindakan untuk mengunjungi dan berlanjut lama sesudahnya. Proses kunjungan diawali dengan adanya masalah atau kebutuhan yang dirasakan pengunjung, mempersepsikan perbedaan antara keadaan yang diinginkan dengan situasi saat ini guna membangkitkan dan mengaktifkan proses keputusan. Pemasar perlu memusatkan perhatian pada proses kunjungan secara keseluruhan bukannya hanya pada keputusan untuk berkunjung. Berikut proses keputusan berkunjung yang dikemukakan oleh Kotler (2009:208)

GAMBAR 2.1

PROSES KEPUTUSAN BERKUNJUNG

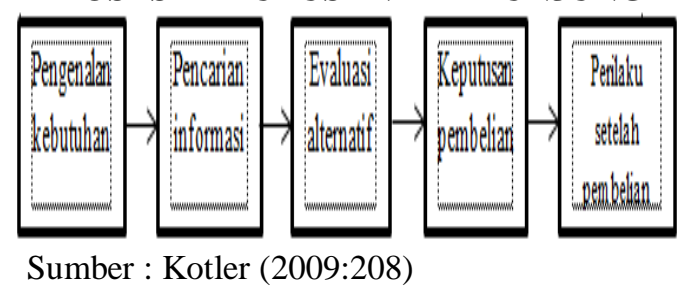

Penelitian ini akan membahas lima keputusan yang diambil yaitu pemilihan produk/jasa, pemilihan merek (brand), penentuan jumlah kunjungan dan penentuan waktu kunjungan serta (Schiffman dan Kanuk, 2000:628).

\subsection{KERANGKA PEMIKIRAN}

Perusahaan tidak hanya harus berhubungan secara konstruktif dengan pengunjung, pemasok dan penyalur, tetapi ia juga harus berhubungan dengan kumpulan kepentingan publik yang besar. Betapa berkualitasnya sesuatu, bila pengunjung belum pernah mendengarnya dan tidak yakin bahwa produk itu akan berguna bagi mereka, maka mereka tidak akan pernah 
membelinya. Pemasaran berhubungan dengan mengidentifikasi dan memenuhi kebutuhan manusia dan masyarakat. Jasa sering dipandang sebagai suatu fenomena yang rumit. Kata 'jasa' (service) itu sendiri mempunyai banyak arti, mulai dari pelayanan pribadi (personal service) sampai jasa sebagai suatu produk. Jasa memiliki karakteristik yang berbeda dengan produk barang (fisik).

Berbagai strategi pemasaran yang dapat dilakukan oleh perusahaan terhadap strategi generik akan bergantung pada analisis lingkungan usaha untuk menentukan peluang dan ancaman. Menurut Porter (2008:51):

"keunggulan bersaing berasal dari banyak aktivitas berlainan yang dilakukan oleh perusahaan dalam mendesain, memproduksi, memasarkan, menyampaikan, dan mendukung produknya. Masingmasing aktivitas ini dapat mendukung posisi biaya relatif perusahaan dan menciptakan dasar untuk diferensiasi."

Dalam strategi ini, perusahaan menjadi produsen berbiaya rendah dalam industri. Keunggulan biaya merupakan salah satu dari tiga jenis keunggulan bersaing yang mungkin dimiliki perusahaan. Dalam hal ini biaya juga sangat penting bagi strategi diferensiasi karena diferensiator harus mempertahankan kedekatan biaya dengan para pesaing. Apabila premi harga yang dihasilkan melebihi biaya diferensiasi, maka diferensiator akan tidak berhasil mencapai kinerja unggul. Perilaku biaya juga menimbulkan pengaruh kuat terhadap struktur industri secara menyeluruh. Dalam strategi ini, perusahaan menjadi unik dalam industrinya dalam sejumlah dimensi tertentu. Strategi ini cirinya adalah bahwa perusahaan mengambil keputusan untuk membangun persepsi pasar potensial terhadap suatu produk/jasa yang unggul agar tampak berbeda dengan produk yang lain. Dengan demikian, diharapkan calon konsumen mau membeli dengan harga mahal karena adanya perbedaan itu.

Strategi diferensiasi yang dapat didesain perusahaan meliputi diferensiasi produk, pelayanan, personil, saluran distribusi, dan citra. Diferensiasi produk yang ditawarkan dengan berbagai atribut menarik (bentuk, keistimewaan, kinerja, kesesuaian, daya tahan, keandalan, mudah diperbaiki, gaya, rancangan) tentunya akan memberi kepuasan tersendiri bagi konsumen untuk melakukan keputusan pembelian.

Diferensiasi pelayanan meliputi berbagai jasa yang memberikan kemudahan pemesanan, pengiriman, pemasangan, pelatihan pengunjung, konsultasi pengunjung, pemeliharaan dan perbaikan (contohnya : online reservation dan pemberian garansi.

Diferensiasi saluran distribusi berupa pemilihan partner bisnis yang kompeten untuk memberikan berbagi kemudahan pada konsumen dalam melakukan pembelian produk-produk perusahaan dan penempatan lokasi perusahaan yang mudah dijangkau serta strategis (cakupan, keahlian, kinerja).

Diferensiasi personil berupa kinerja tenaga-tenaga profesional atau ahli yang akan menyampaikan janji perusahaan (pemasaran interaktif; deliver the promise). Hal ini dapat berupa kemampuan karyawan, kesopanan, karyawan yang dapat dipercaya, dapat diandalkan, cepat tanggap, dan komunikasi.

Diferensiasi citra perusahaan dapat mendesain suatu slogan atau simbol tertentu yang melambangkan berbagai manfaat yang akan diperoleh konsumen dari perusahaan. Diferensiasi citra menentukan posisi perusahaan di benak konsumennya dan juga para pesaing sehingga perusahaan pun dapat mengetahui posisi bisnisnya. Citra yang sangat kuat akan menciptakan keputusan berkunjung yang tinggi kepada konsumen (lambang, media, atmosfir, peristiwa).

Keputusan untuk membeli timbul karena adanya penilaian yang objektif atau dorongan emosi. Menurut Kotler \& Amstrong (2008:158), perilaku pembelian konsumen mengacu kepada perilaku pembelian akhir perorangan dan rumah tangga yang membeli barang atau jasa untuk konsumsi pribadi. Keputusan untuk bertindak adalah hasil dari serangkaian aktivitas dan rangsangan mental serta emosional. Semakin komplek keputusan, biasanya akan melibatkan semakin banyak pihak yang terkait dan semakin banyak pertimbangan. Proses keputusan untuk berkunjung dipegaruhi oleh bermacammacam dorongan. Saat seseorang membeli suatu produk baik barang maupun jasa, belum tentu orang tersebut telah memutuskan berkunjung untuk membeli sebuah produk tersebut yang merupakan produk yang paling disukainya.

Kotler dan Keller (2009:202)


pembelian ada pada tahap keempat dalam proses keputusan pembelian dimana keputusan pembelian terdiri dari enam tahapan yaitu:1) Pemilihan produk, 2) Pemilihan merek, 3) Pemilihan penyalur, 4) Waktu pembelian, 5) Jumlah pembelian, dan 6) Metode Pembayaran.

Untuk mendorong keputusan berkunjung dari pengunjung terhadap produknya, sebuah objek wisata dituntut untuk memperlihatkan produk yang unggul yaitu salah satunya melalui pemilihan desain produk yang menarik, dan dipromosikan dan diantaranya dengan menciptakan keunggulan bersaing yang baik, agar mampu memenuhi selera pengunjung secara memuaskan. Variabel ini mempunyai peranan penting dalam mempengaruhi keputusan berkunjung.

Sangat jelas bahwa dalam proses perilaku keputusan berkunjung, keunggulan bersaing memegang peranan penting yang harus diperhatikan oleh perusahaan dalam mempengaruhi keputusan berkunjung. Selanjutnya model kerangka berfikir dalam penelitian ini digambarkan sebagai berikut :

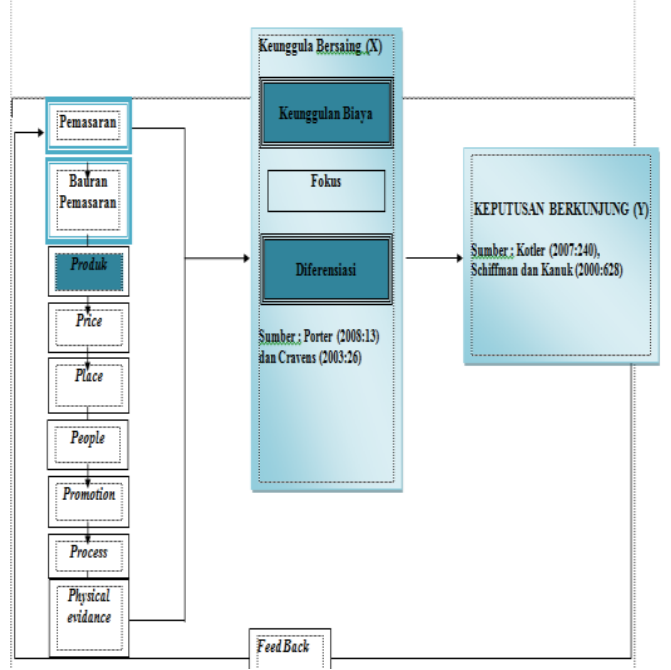

Sumber : Kotler dan Amstrong (2008 :71)

\section{GAMBAR 2.2 KERANGAKA PEMIKIRAN}

Berdasarkan kerangka pemikiran pada Gambar 2.2 tersebut di atas dapat digambarkan paradigma penelitian strategi keunggulan bersaing terhadap keputusan berkunjung dengan dimensi kepemimpinan biaya dan diferensiasi. Sedangkan keputusan berkunjung adalah pemilihan produk, pemilihan merek, pemilihan penyalur, waktu kunjungan, dan jumlah kunjungan. Secara jelas paradigma penelitian digambarkan pada Gambar 2.3 sebagai berikut:

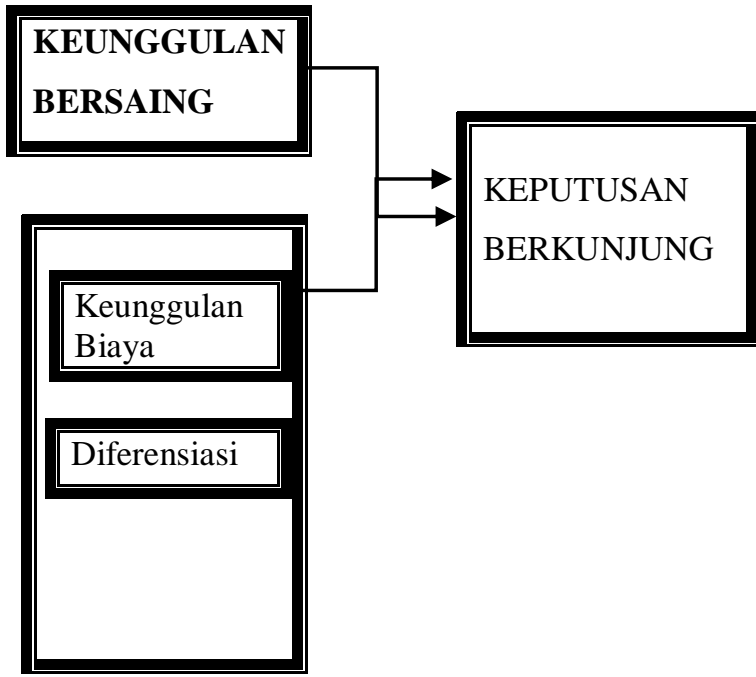

\section{GAMBAR 2.3 \\ PARADIGMA PENELITIAN}

\subsection{HIPOTESIS}

Menurut Suharsimi Arikunto (2009:160) mennyatakan bahwa Hipotesis merupakan jawaban yang bersifat sementara terhadap permasalahan penelitian, sampai terbukti melalui data yang terkumpu. "Hipotesis merupakan jawaban sementara terhadap rumusan masalah penelitian. Karena sifatnya masih sementara, maka perlu dibuktikan kebenarannya melalui data empirik yang terkumpul (Sugiyono, 2008:328).

Peneliti dalam menyusun hipotesis didukung oleh beberapa premis sebagai berikut :

1. Porter (2008:13)

Strategi bersaing adalah pencarian posisi bersaing yang menguntungkan di dalam suatu industri, dan merupakan arena yang fundamental tempat persaingan terjadi.

2. R. Reinarsyah Iskandar (2000:18)

perusahaan yang menjual produk dan kualitas yang sama akan mengalami persaingan yang sangat kompetitif, dengan perusahaan yang telah lebih dahulu berdiri di pasar jika perusahaan tersebut tidak melakukan salah satu dr strategi keunggulan bersaing produk dalam menembus pasar maka akan mudah tergeser sehingga dengan melakukan strategi ini akan mampu 
menciptakan tingkat kunjungan yang tinggi.

Berdasarkan kerangka pemikiran maka hipotesis yang diajukan dalam penelitian ini sebagai berikut:

"Terdapat pengaruh yang signifikan pada keunggulan bersaing yang terdiri dari keunggulan biaya dan diferensiasi terhadap keputusan berkunjung di kawasan wisata air panas Taman Air Sabda Alam Cipanas Kabupaten Garut.

\section{METODE PENELITIAN}

\subsection{Objek Penelitian}

Penelitan ini menggunakan pendekatan ilmu manajemen pemasaran dengan fokus pada bidang manajemen pemasaran pariwisata khususnya yang berkaitan dengan strategi keunggulan bersaing serta pengaruhnya terhadap keputusan berkunjung. Penelitian ini dilakukan untuk menganalisis mengenai Pengaruh Keunggulan Bersaing di Kawasan Air Panas Taman Air Sabda Alam Hotel dan Resort Cipanas Kabupaten Garut dalam Meningkatkan Keputusan Berkunjung (survei terhadap pengunjung di Kawasan Wisata Air Panas Taman Air Sabda Alam).

Pada penelitian ini digunakan metode deskriptif dan verifikatif. Penelitian deskriptif disini bertujuan untuk memperoleh deskripsi tentang permasalahan yang diteliti. Melalui jenis penelitian deskriptif ini, maka dapat diperoleh deskripsi mengenai gambaran Pengaruh Keunggulan Bersaing di Kawasan Wisata Air Panas Taman Air Sabda Alam Cipanas Kabupaten Garut dalam Meningkatkan Keputusan Berkunjung.

Penelitian verifikatif pada dasarnya ingin menguji kebenaran suatu hipotesis yang dilakukan melalui pengumpulan data di dalam lapangan. Dalam hal ini penelitian verifikatif bertujuan untuk mengetahui Keunggulan Bersaing dalam meningkatkan Keputusan Berkunjung di Kawasan Air Panas Taman Air Sabda Alam.

Berdasarkan jenis penelitian di atas yaitu penelitian deskriptif dan verifikatif yang dilaksanakan melalui pengumpulan data dilapangan, maka metode yang digunakan adalah explanatory survey. Penelitian yang menggunakan metode ini, melakukan kegiatan pengumpulan informasi dari sebagian populasi secara langsung di tempat kejadian (empirik) dengan tujuan untuk mengetahui pendapat dari sebagian populasi terhadap objek yang sedang diteliti.
Metode pengembangan yang dipergunakan adalah cross-sectional method. Pada penelitian dengan menggunakan metode ini, informasi dari sebagian populasi dikumpulkan langsung ditempat kejadian secara empirik dengan tujuan untuk mengetahui pendapat dari sebagian populasi terhadap objek yang sedang diteliti.

\subsection{Operasionalisasi Variabel}

Variabel yang akan dikaji dalam penelitian ini meliputi Keunggulan Bersaing (X) yang terdiri dari keunggulan biaya $\left(\mathrm{X}_{1}\right)$ dan diferensiasi $\left(\mathrm{X}_{2}\right)$. Sedangkan variabel terikat adalah keputusan berkunjung yang terdiri dari pemilihan produk/jasa, pemilihan merek, pemilihan penyalur, pemilihan, waktu berkunjung, dan jumlah kunjungan. 
TABEL 3.1

OPERASIONALISASI VARIABEL PENELITIAN

\begin{tabular}{|c|c|c|c|c|c|}
\hline $\begin{array}{c}\text { Variabel/ } \\
\text { Sub bariabel }\end{array}$ & $\begin{array}{c}\text { Konsep } \\
\text { Variabel }\end{array}$ & Indikator & Ukuran & Skala & No. Item \\
\hline $\begin{array}{l}\text { Keunggulan } \\
\text { Bersaing (X) }\end{array}$ & $\begin{array}{l}\text { keunggulan bersaing } \\
\text { berasal dari banyak } \\
\text { aktivitas berlainan yang } \\
\text { dilakukan oleh perusahaan } \\
\text { dalam mendesain, } \\
\text { memproduksi, } \\
\text { memasarkan, } \\
\text { menyampaikan, dan } \\
\text { mendukung produknya. } \\
\text { Masing-masing aktivitas ini } \\
\text { dapat mendukung posisi } \\
\text { biaya relatif perusahaan } \\
\text { dan menciptakan dasar } \\
\text { untuk diferensiasi. Porter } \\
\text { (2008:51) }\end{array}$ & & & & \\
\hline $\begin{array}{c}\text { Keunggulan } \\
\text { biaya }\left(\mathrm{X}_{1}\right)\end{array}$ & $\begin{array}{l}\text { memperhitungkan pesaing } \\
\text { daripada pengunjung } \\
\text { dengan cara harga jual } \\
\text { produk yang murah, } \\
\text { sehingga biaya produksi, } \\
\text { promosi maupun riset dapat } \\
\text { ditekan. (Porter,2008:9) }\end{array}$ & $\begin{array}{r}\text { - Biaya } \\
\text { rendah }\end{array}$ & $\begin{array}{c}\text { - Tingkat kesesuaian harga tiket } \\
\text { masuk ke kolam renang dan } \\
\text { taman air yang ditawarkan } \\
\text { sesuai dibanding pesaing } \\
\text { - Tingkat kesesuaian biaya sewa } \\
\text { alat rekreasi yang murah (ban, } \\
\text { baju renang, dll) } \\
\text { - Tingkat kesesuaian harga yang } \\
\text { ditawarkan terhadap pelayanan } \\
\text { yang didapat pengunjung } \\
\text { selama berada di daya tarik } \\
\text { wisata Taman Air Sabda Alam } \\
\text { - Tingkat kesesuaian biaya yang } \\
\text { ditawarkan terhadap } \\
\text { kemudahan mengakses lokasi } \\
\text { - Tingkat kesesuaian biaya yang } \\
\text { ditawarkan dengan } \\
\text { kenyamanan tempat parkir } \\
\text { - Tingkat kesesuaian biaya yang } \\
\text { ditawarkan dengan keamanan } \\
\text { lokasi } \\
\text { - Tingkat kesesuaian biaya yang } \\
\text { ditawarkan dengan manfaat } \\
\text { yang didapat dari daya tarik } \\
\text { wisata Taman Air Sabda Alam } \\
\text { Tingkat kesesuaian biaya yang } \\
\text { ditawarkan dengan } \\
\text { kemampuan daya beli } \\
\text { - Tingkat kesesuaian harga } \\
\text { dengan kulitas yang diterima } \\
\text { anda di daya tarik wisata } \\
\text { Taman Air Sabda Alam } \\
\end{array}$ & $\begin{array}{l}\text { - } \begin{array}{c}\text { ordinally } \\
\text { Scale } \\
\text { - } \\
\text { ordinally } \\
\text { Scale } \\
\text { - ordinally } \\
\text { Scale } \\
\text { - ordinally } \\
\text { Scale } \\
\text { - ordinally } \\
\text { Scale } \\
\text { - ordinally } \\
\text { Scale } \\
\text { ordinally } \\
\text { Scale } \\
\\
\text { - ordinally } \\
\text { Scale } \\
\text { ordinally } \\
\text { Scale } \\
\text { - ordinally } \\
\text { Scale } \\
\text { ordinally } \\
\text { Scale } \\
\text { ordinally }\end{array} \\
\end{array}$ & $\begin{array}{l}\text { III.A1 } \\
\text { III.A2 } \\
\text { III.A3 } \\
\text { III.A4 } \\
\text { III.A5 } \\
\text { III.A6 } \\
\text { III.A7 } \\
\text { III.A8 } \\
\text { III.A9 } \\
\text { III.A10 } \\
\text { III.A11 } \\
\end{array}$ \\
\hline
\end{tabular}




\begin{tabular}{|c|c|c|c|c|c|}
\hline & & $\begin{array}{c}\text { - } \begin{array}{c}\text { Potongan } \\
\text { harga }\end{array} \\
\text {. }\end{array}$ & $\begin{array}{c}\text { - Tingkat kesesuaian manfaat } \\
\text { yang dirasakan dari daya tarik } \\
\text { wisata Taman Air Sabda Alam } \\
\text { - Tingkat Kemampuan produk } \\
\text { wisata dalam memenuhi } \\
\text { kebutuhan anda di daya tarik } \\
\text { wisata Taman Air } \\
\text { - Tingkat Persepsi anda } \\
\text { terhadap harga tarif di daya } \\
\text { tarik wisata Taman Air Sabda } \\
\text { Alam } \\
\text { - Tingkat kesesuaian potongan } \\
\text { harga untuk tiket masuk yang } \\
\text { ditawarkan terhadap } \\
\text { pengunjung } \\
\text { - Tingkat kesesuaian potongan } \\
\text { harga yang ditawarkan pada } \\
\text { saat event-event tertentu } \\
\text { - Tingkat kesesuaian potongan } \\
\text { harga yang ditawarkan pada } \\
\text { saat weekday dibanding } \\
\text { pesaing } \\
\text { - Tingkat kesesuaian potongan } \\
\text { harga yang ditawarkan pada } \\
\text { saat weekend dan hari libur } \\
\text { dibanding pesaing }\end{array}$ & $\begin{array}{c}\text { Scale } \\
\text { - } \quad \begin{array}{c}\text { ordinally } \\
\text { Scale }\end{array} \\
\text { - } \quad \begin{array}{c}\text { ordinally } \\
\text { Scale }\end{array} \\
\text { - } \quad \text { ordinally } \\
\text { Scale } \\
\text { - } \quad \text { rdinally } \\
\text { Scale }\end{array}$ & $\begin{array}{l}\text { III.A13 } \\
\text { III.A14 } \\
\text { III.A15 } \\
\text { III.A16 }\end{array}$ \\
\hline \multirow[t]{2}{*}{$\begin{array}{l}\text { Diferensiasi } \\
\quad\left(\mathrm{X}_{3}\right)\end{array}$} & $\begin{array}{c}\text { Diferensiasi merupakan } \\
\text { salah satu dari dua jenis } \\
\text { keunggulan bersaing yang } \\
\text { bisa dimiliki perusahaan } \\
\text { selain dari keunggulan biaya. } \\
\text { Perusahaan berusaha } \\
\text { menjadi unik dalam } \\
\text { industrinya di beberapa } \\
\text { dimensi yang secara umum } \\
\text { dihargai oleh pembeli. } \\
\text { (porter,2008:29) }\end{array}$ & & & & \\
\hline & & $\begin{array}{c}\text { Diferensiasi } \\
\text { Produk }\end{array}$ & $\begin{array}{c}\text { - Tingkat keragaman jenis } \\
\text { kolam (bentuk, luas dan } \\
\text { kedalaman) } \\
\text { - Tingkat kelengkapan } \\
\text { fasilitas kolam (kamar bilas, } \\
\text { ruang ganti, kamar mandi, } \\
\text { dan kamar berendam) } \\
\text { - Tingkat kesesuaian kualitas } \\
\text { sumber air panas } \\
\text { - Tingkat kesesuaian } \\
\text { Temperatur air panas } \\
\text { - Tingkat keragaman } \\
\text { Aktivitas yang bisa } \\
\text { dilakukan di kolam renang }\end{array}$ & 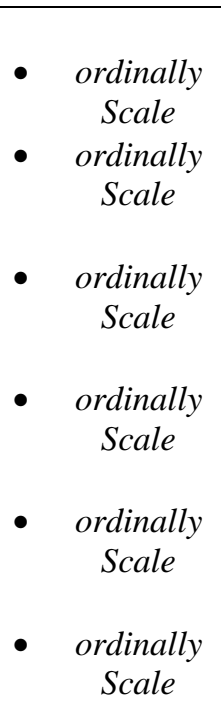 & $\begin{array}{l}\text { III.B1 } \\
\text { III.B2 } \\
\text { III.B3 } \\
\text { III.B4 } \\
\text { III.B5 } \\
\text { III.B6 }\end{array}$ \\
\hline
\end{tabular}




\begin{tabular}{|c|c|c|c|c|c|}
\hline & & & $\begin{array}{c}\text { - Tingkat kemudahan } \\
\text { menukar alat sewa yang } \\
\text { tidak sesuai dengan } \\
\text { keinginan } \\
\text { - Tingkat kemenarikan } \\
\text { artistik Desain Taman Air } \\
\text { Taman Air Sabda Alam }\end{array}$ & $\begin{array}{c}\text { ordinally } \\
\text { Scale }\end{array}$ & III.B7 \\
\hline & & $\begin{array}{c}\text { Diferensiasi } \\
\text { Pelayanan }\end{array}$ & $\begin{array}{l}\text { - Tingkat kemudahan dalam } \\
\text { pemesanan tiket kolam } \\
\text { renang dan taman air } \\
\text { - Tingkat penyediaan } \\
\text { kebutuhan pengunjung } \\
\text { (fasilitas dan kebutuhan } \\
\text { berenang, café, internet } \\
\text { acces, area parker yang luas } \\
\text { dll). } \\
\text { - Tingkat kemudahan dalam } \\
\text { mencari informasi di Taman } \\
\text { Air Sabda Alam } \\
\text { Tingkat kebersihan kolam } \\
\text { renang dan hotel }\end{array}$ & $\begin{array}{c}\text { - } \begin{array}{c}\text { ordinally } \\
\text { Scale }\end{array} \\
\text { - } \quad \begin{array}{c}\text { ordinally } \\
\text { Scale }\end{array} \\
\text { - ordinally } \\
\text { Scale } \\
\text { ordinally } \\
\text { Scale }\end{array}$ & $\begin{array}{l}\text { III.B9 } \\
\text { III.B10 } \\
\text { III.B11 }\end{array}$ \\
\hline & & $\begin{array}{c}\text { Diferensiasi } \\
\text { personel }\end{array}$ & $\begin{array}{c}\text { - Tingkat kinerja karyawan } \\
\text { yang dapat diandalkan. } \\
\text { - Tingkat daya tanggap } \\
\text { karyawan dalam melayani } \\
\text { pengunjung. } \\
\text { - Tingkat Attitude karyawan } \\
\text { dalam memberikan informasi } \\
\text { dan menanggapi keluhan } \\
\text { pengunjung }\end{array}$ & $\begin{array}{c}\text { - } \begin{array}{c}\text { ordinally } \\
\text { Scale }\end{array} \\
\text { - } \begin{array}{c}\text { ordinally } \\
\text { Scale }\end{array} \\
\text { - ordinally } \\
\text { Scale }\end{array}$ & $\begin{array}{l}\text { III.B12 } \\
\text { III.B13 } \\
\text { III.B14 }\end{array}$ \\
\hline & & $\begin{array}{c}\text { Diferensiasi } \\
\text { Citra }\end{array}$ & $\begin{array}{l}\text { - Popularitas nama } \\
\text { pemandian air panas } \\
\text { Cipanas } \\
\text { - Tingkat kesesuaian } \\
\text { pemenuhan janji pemandian } \\
\text { air panas Cipanas dengan } \\
\text { bukti pelayanan yang } \\
\text { diberikan }\end{array}$ & $\begin{array}{l}\text { ordinally } \\
\text { Scale } \\
\text { ordinally } \\
\text { Scale }\end{array}$ & $\begin{array}{l}\text { III.B16 } \\
\text { III.B17 }\end{array}$ \\
\hline \multirow{2}{*}{$\begin{array}{c}\text { Keputusan } \\
\text { Berkunjung } \\
\text { (Y) }\end{array}$} & \multirow{2}{*}{$\begin{array}{l}\text { Tahap dalam pengambilan } \\
\text { keputusan di mana } \\
\text { pengunjung benar-benar } \\
\text { menggunakan produk/jasa } \\
\text { wisata. Kotler \& Keller }\end{array}$} & & & & \\
\hline & & $\begin{array}{c}\text { pilihan } \\
\text { Produk/jasa }\end{array}$ & $\begin{array}{c}\text { - Tingkat Daya tarik wisata } \\
\text { Taman Air Taman Air Sabda } \\
\text { Alam dibanding dengan } \\
\text { pesaing }\end{array}$ & $\begin{array}{l}\text { - ordinally } \\
\text { Scale } \\
\text { - ordinally }\end{array}$ & $\begin{array}{l}\text { IV.A1 } \\
\text { IV.A2 }\end{array}$ \\
\hline
\end{tabular}




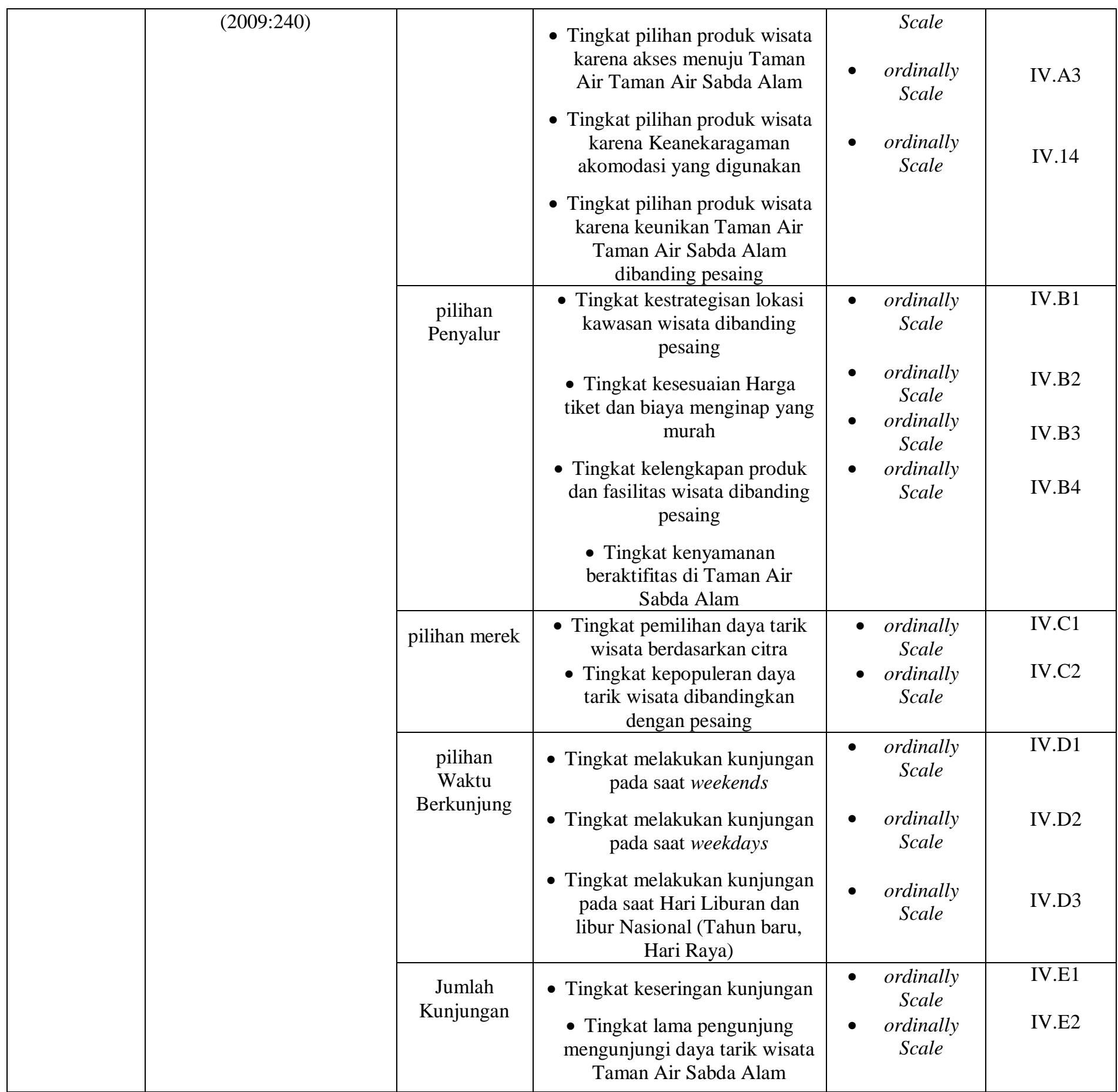

Sumber: pengolahan data 2011

\subsection{Populasi}

Sample dalam penelitian ini yaitu menggunakan Pengunjung Taman Air Sabda Alam Hotel \& Resort. Jumlah sample yang diambil dalam penelitian ini adalah 100 sampel

dari jumlah populasi pengunjung pada tahun 2010 sebanyak 8674 dengan menggunakan rumus Slovin.

\subsection{Teknik Pengumpulan Data}

Teknik pengumpulan data merupakan cara untuk mencari dan memperoleh data mengenai variabel-variabel data yang diperlukan. Sugiyono (2008:137) mengutarakan bahwa "Bila dilihat dari segi cara atau teknik pengumpulan data, maka teknik pengumpulan data dapat dilakukan dengan interview (wawancara), kuesioner 
(angket), observasi (pengamatan), dan studi literatur".

\section{HASIL PENELITIAN DAN} PEMBAHASAN

4.1 Pembahasan Hasil Tanggapan

Pengunjung Mengenai Keunggulan

Bersaing Di Tama Air Sabda Alam

Berdasarkan hasil pengolahan data varibel $\mathrm{x}$, diperoleh rekapitulasi tanggapan pengunjung mengenai Keunggulan Bersaing Taman Air Sabda Alam yang tersaji pada Tabel 4.43 berikut :

TABEL 4.43

REKAPITULASI TANGGAPAN PENGUNJUNG MENGENAI KEUNGGULAN BERSAING

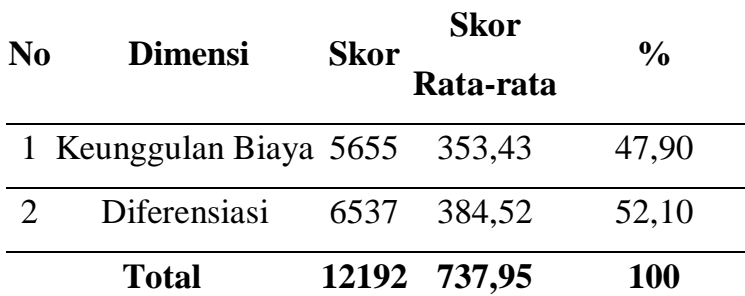

Sumber: Hasil pengolahan data 2011

Berdasarkan Tabel 4.43 bahwa dimensi yang memiliki penilaian tertinggi yaitu diferensiasi sebesar 52,10\%. Dengan demikian, sebagian besar pengunjung merasakan keunikan produk wisata yang dimiliki Taman Air Sabda Alam sangat berbeda dengan produk wisata pesaingnya. Hal ini dikarenakan Taman Air Sabda Alam selalu melakukan berbagai perubahan dalam mengembangkan produk wisatanya sebagai kawasan wisata yang lengkap, selalu berinovasi terhadap produk yang dimiliki, mampu memuaskan dan memenuhi kebutuhan pengunjung. Selain itu, Taman Air Sabda Alam juga memiliki banyak keunikan yang dapat menjadi ciri khas sebagai kawasan air panas terlengkap di Kabupaten Garut.

Berbagai produk wisata yang ada di Taman Air Sabda Alam ini yaitu seperti Nampan Tumpah dimana airnya akan tumpah saat pengunjung berada dibawahnya. Wahana lainnya yang ada di kawasan wisata Taman Air Sabda Alam yaitu Bola pasir, Flying Fox, Canoe, ATV, Spiral dan yang terbaru adalah Water Ball yang merupakan bola raksasa yang mengambang di atas air dimana kita bisa masuk dan berjalan di dalam bola. Selain diwahananya, Taman Air Sabda Alam juga melakukan diferensiasi produk dengan memberikan fasilitas pelengkap lainnya berupa kamar-kamar hotel yang terbagi kedalam beberapa jenis (Meriah Rooms, Indah Rooms, Anggun Suite, Asri, dan Asri Suite), dua buah bungalow dan fasilitas hotel lainnya yaitu Sawala Meeting Room, Bogarasa Restoran, Kolam Pancing dan rakit. Hal ini merupakan sebagai pelengkap produk wisata bagi pengunjung yang akan melakukan berbagai kegiatan wisata.

Dalam persaingan, diferensiasi pada suatu perusahaan akan menjadi unik dalam industrinya selama banyak melakukan inovasi. Sehinga disepanjang beberapa dimensi yang secara umum akan dihargai oleh pengunjung, perusahaan harus lebih baik lagi menyeleksi satu atau lebih atribut yang dipandang penting oleh banyak pembeli di dalam suatu industri dan secara unik menempatkan diri untuk memenuhi kebutuhan itu.

Berikut adalah gambar mengenai rekapitulasi hasil tanggapan pengunjung terhadap keunggulan bersaing Taman Air Taman Air Sabda Alam yang disajikan pada Gambar 4.10 berikut:

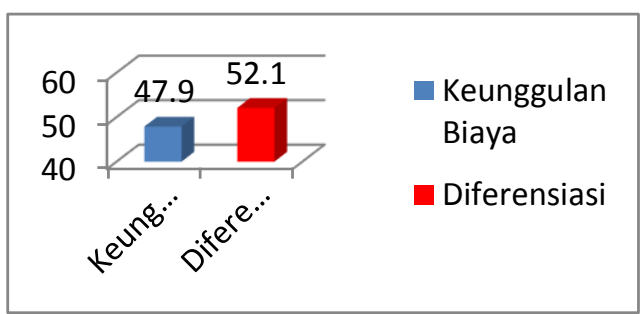

Sumber: Hasil pengolahan data 2011

\section{GAMBAR 4.10 \\ REKAPITULASI TANGGAPAN \\ PENGUNJUNG MENGENAI KEUNGGULAN BERSAING}

\subsection{Pembahasan Hasil Tanggapan Mengenai Keputusan Berkunjung Ke Taman Air Sabda Alam}

Keputusan pengunjung untuk mengunjungi atraksi wisata Taman Air Sabda ALam didasari oleh adanya pilihan produk, pilihan merek, pilihan waktu, dan jumlah kunjungan. Berdasarkan hasil pengolahan data varibel $y$, diperoleh rekapitulasi tanggapan pengunjung mengenai keputusan pembelian Taman Air Taman Air Sabda Alam yang tersaji pada Tabel 4.59 berikut: 
TABEL 4.59

REKAPITULASI TANGGAPAN PENGUNJUNG MENGENAI KEPUTUSAN BERKUNJUNG

\begin{tabular}{|c|c|c|c|c|}
\hline No & Dimensi & Skor & $\begin{array}{c}\text { Skor } \\
\text { Rata- } \\
\text { rata }\end{array}$ & $\%$ \\
\hline 1 & $\begin{array}{c}\text { Pemilihan } \\
\text { Produk atau Jasa }\end{array}$ & 1412 & 353 & 20,47 \\
\hline 2 & $\begin{array}{c}\text { Pemilihan } \\
\text { Penyalur }\end{array}$ & 1416 & 354 & 20,52 \\
\hline 3 & Pemilihan merek & 610 & 305 & 17,69 \\
\hline 4 & $\begin{array}{c}\text { Waktu } \\
\text { berkunjung } \\
\text { Tingkat } \\
\text { kunjungan }\end{array}$ & 997 & 332,3 & 19,26 \\
\hline 5 & Total & $\mathbf{5 1 9 6}$ & $\mathbf{1 7 2 4 . 8}$ & $\mathbf{1 0 0}$ \\
\hline
\end{tabular}

Sumber: Hasil pengolahan data 2011

Berdasarkan hasil rekapitulasi pada Tabel 4.59 dapat dilihat bahwa dimensi yang memiliki nilai tertinggi adalah tingkat kunjungan yaitu sebesar 22,06\%. Hal ini dikarenakan, pengunjung yang datang ke taman air sabda alam dapat melakukan aktivitas wisatanya yang beraneka ragam dibandig dengan pesaingya. Selain itu, lokasi Taman Air Sabda Alam yang strategis sehingga membuat pengunjung menjadi sering untuk berwisata, serta memiliki aksesibilitas yang mudah dijangkau.

Sedangkan penilaian terendah adalah dimensi pilihan merek, yaitu sebesar 17,69\%. Hal ini dikarenakan Taman Air Sabda Alam masih harus meningkatkan citranya sebagai kawasan wisata yang memiliki keunikan yang tidak dimiliki oleh pesaingnya di kawasan Air Panas Cipanas.

Berikut adalah gambar mengenai rekapitulasi hasil tanggapan pengunjung terhadap keputusan berkunjung pada Taman Air Taman Air Sabda Alam yang disajikan pada Gambar 4.11 berikut:

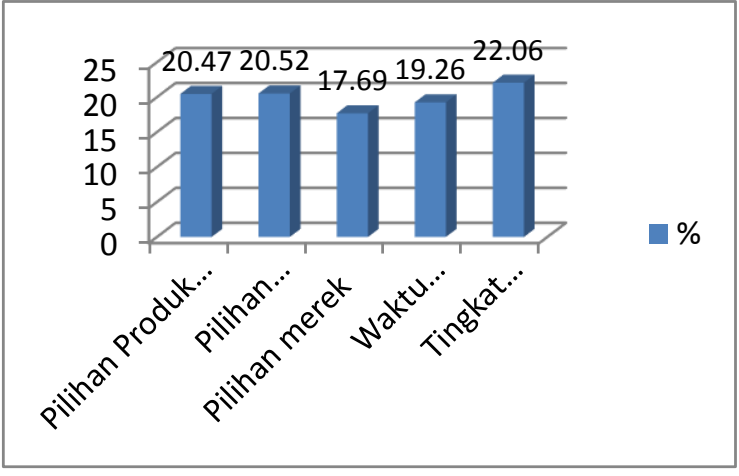

Sumber : Pengolahan data 2011

GAMBAR 4.11

REKAPITULASI TANGGAPAN

PENGUNJUNG MENGENAI

KEPUTUSAN BERKUNJUNG

TAMAN AIR SABDA ALAM

4.3 Pembahasan Pengaruh Keunggulan

Bersaing Terhadap Keputusan

Berkunjung Taman Air Sabda Alam

Hipotesis yang akan diuji dalam penelitian ini adalah pengaruh keunggulan bersaing terhadap keputusan berkunjung di Taman Air Sabda Alam. Pengujian pengaruh variabel ini menggunakan software SPSS 17 For Windows.

\subsubsection{Hasil Uji Asumsi Variabel Pengujian Asumsi Regresi}

a) Hasil Uji Asumsi Normalitas

Menurut Suliyanto (2005:63), uji normalitas dimaksudkan untuk mengetahui apakah residual yang diteliti berdistribusi normal atau tidak. Nilai residual berdistribusi normal merupakan suatu kurva berbentuk lonceng (bellshaped-curve) yang kedua sisinya melebar sampai tidak terhingga.

Distribusi data tidak normal, karena terdapat nilai ekstrim dalam data yang diambil. Cara mendeteksinya dengan menggunakan histogram regression residual yang sudah distandarkan. 
TABEL 4.60

MATRIK KORELASI ANTAR VARIABEL BEBAS

Correlations

\begin{tabular}{|ll|r|r|r|}
\hline & & Keputusan & Keunggulan \\
Berkunjung & Biaya & Diferensiasi \\
\hline Pearson Correlation & Keputusan Berkunjung & 1.000 & .633 & .762 \\
& Keunggulan Biaya & .633 & 1.000 & .737 \\
& Diferensiasi & .762 & .737 & 1.000 \\
\hline Sig. (1-tailed) & Keputusan Berkunjung &. & .000 & .000 \\
& Keunggulan Biaya & .000 &. & .000 \\
& Diferensiasi & .000 & .000 & \\
\hline $\mathrm{N}$ & Keputusan Berkunjung & 100 & 100 & 100 \\
& Keunggulan Biaya & 100 & 100 & 100 \\
& Diferensiasi & 100 & 100 & 100 \\
\hline
\end{tabular}

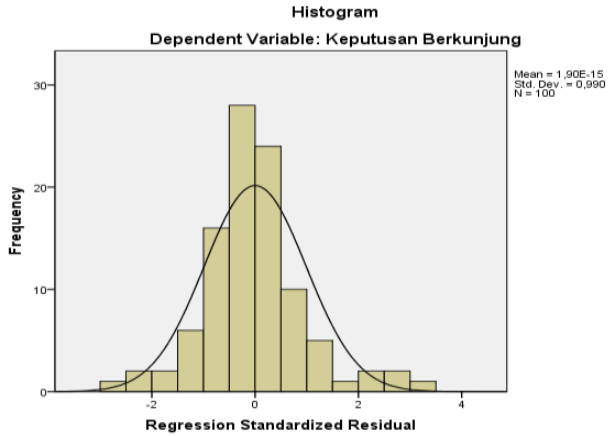

Sumber : Pengolahan data 2011

GAMBAR 4.12

HISTOGRAM KEPUTUSAN BERKUNJUNG

Berdasarkan Gambar 4.11 di atas, dapat dikatakan bahwa model berdistribusi normal, karena kurva membentuk lonceng. Pengujian ini dilakukan dengan menggunakan normal probability plot. Gambar 4. di bawah ini menggambarkan normal probability plot yang digunakan untuk mendeteksi apakah data yang digunakan berdistribusi normal atau tidak.

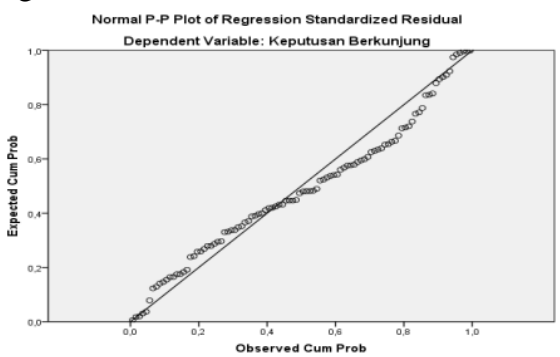

GAMBAR 4.13

NORMAL PROBABILITY PLOT
Suatu model regresi layak dipakai apabila nilai residunya mengikuti distribusi normal, pada Gambar 4.12 di atas nilai residu berdistribusi normal apabila sebaran datanya terletak di sekitar garis diagonal yaitu dari kiri bawah ke kanan atas.

\section{b. Hasil Uji Asumsi Multikolinearitas}

Multikolinearitas artinya terdapat hubungan linear yang sempurna atau pasti diantara beberapa atau semua variabel yang menjelaskan dari model regresi, yaitu terdapatnya lebih dari satu hubungan linear pasti. Berdasarkan teori tersebut, maka dalam penelitian ini terdapat korelasi yang rendah antara variabel bebas dapat dijelaskan. Untuk mengetahui terjadinya multikolinearitas dalam penelitian ini digunakan matriks korelasi yang dihitung dengan bantuan paket program SPSS pada tabel 4.60 berikut:

Berdasarkan Tabel 4.60 di atas menunjukkan bahwa korelasi antar variabel bebas tidak terdapat nilai yang melebihi 0.80 (semua kurang dari 0.80), dengan demikian tidak terjadi multikolinearitas, dengan mengacu pada Gujaratai (2003:362) mengemukakan bahwa apabila korelasi antar variabel bebas tidak terdapat nilai lebih dari 0.80 maka tidak terjadi multikolinearitas.

Menurut Suliyanto (2005:63), untuk mengetahui ada tidaknya multikolinearitas antarvariabel bebas, salah satu caranya adalah dengan melihat dari nilai variance inflation factor (VIF) dari masing-masing variabel bebas terhadap variabel terikatnya. Menurut Algifari (2000) dalam Suliyanto (2005:63), jika nilai VIF tidak lebih dari 5, maka model tidak terdapat multikolinearitas. 
Setelah melalui perhitungan komputer dihasilkan nilai VIF yang lebih kecil dari 5. Hal ini menunjukkan tidak terjadinya gejala multikolinearitas, artinya tidak adanya hubungan antar variabel bebas. Selain menggunakan nilai VIF, dapat pula dengan melihat besarnya nilai koefisien korelasi antar variabel bebasnya. Jika nilai koefisien korelasi antara masing-masing variabel bebasnya tidak lebih dari 0,5 , maka model tersebut tidak mengandung unsur multikolinearitas.

TABEL 4.61

UJI MULTIKORELASI Coefficients $^{\mathrm{a}}$

\begin{tabular}{|c|c|c|}
\hline \multirow[b]{2}{*}{ Model } & \multicolumn{2}{|c|}{ Collinearity Statistics } \\
\hline & Tolerance & VIF \\
\hline $\begin{array}{l}\text { Keunggulan } \\
\text { Biaya }\end{array}$ & ,457 & 2,186 \\
\hline $\begin{array}{l}\text { Diferensias } \\
\mathrm{i}\end{array}$ & ,457 & 2,186 \\
\hline
\end{tabular}

a. Dependent Variable: Keputusan

Berkunjung

Sumber : Pengolahan data 2011

Dari hasil output data didapatkan bahwa nilai semua nilai $\mathrm{VIF}<10$ ini berarti tidak terjadi multikolonieritas. Dan dapat disimpulkan bahwa uji multikolonieritas terpenuhi.

\section{b) Uji Asumsi Heteroskedastisitas}

Heteroskedastisitas adalah varian residual yang tidak konstan pada regresi sehingga akurasi hasil prediksi menjadi meragukan. Residu pada heteroskedastisitas semakin besar apabila pengamatan semakin besar. Menurut wahid Sulaiman (2004:106), suatu regresi dikatakan tidak terdeteksi heteroskedastis apabila penyebaran nilainilai residual terhadap harga-harga prediksi tidak membentuk suatu pola tertentu (meningkat atau menurun). Suatu regresi dikatakan tidak terdeteksi Heteroskedastisita apabila diagram pencar residualnya tidak membentuk pola tertentu, dan apabila datanya berpencar disekitar angka 35 (pada sumbu Y).

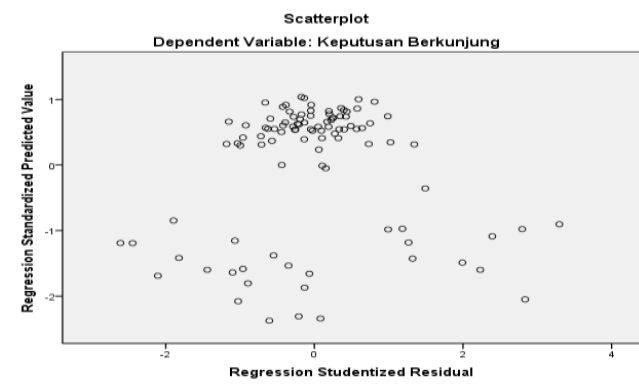

Sumber : Pengolahan data 2011

GAMBAR 4.14

HASIL UJI HETEROKEDASTISITAS

Dari gambar diatas dapat diketahui bahwa tidak terjadi heteroskedastisitas sebab tidak ada pola yang jelas serta titik-titik menyebar di atas dan di bawah angka 0 pada sumbu Y. sehingga dapat dikatakan uji heteroskedastisitas telah terpenuhi.

\subsubsection{Koefisien Korelasi dan Koefisien Determinasi}

Untuk mengetahui seberapa kuat hubungan dan seberapa besar pengaruh keunggulan bersaing yang terdiri keunggulan biaya (X1) dan diferensiasi (X2), dapat dilihat melalui nilai koefisien korelasi dan determinasi.

TABEL 4.62

\section{UJI KOEFISIEN KORELASI}

Model Summary

\begin{tabular}{|l|c|r|r|r|}
\hline Model & $\mathrm{R}$ & $\begin{array}{c}\mathrm{R} \\
\text { Square }\end{array}$ & $\begin{array}{c}\text { Adjusted R } \\
\text { Square }\end{array}$ & $\begin{array}{c}\text { Std. Error of } \\
\text { the Estimate }\end{array}$ \\
\hline 1 &, $769^{\mathrm{a}}$ &, 592 &, 583 & 5,43424 \\
\hline
\end{tabular}

a. Predictors: (Constant), Diferensiasi, Keunggulan Biaya

b. Dependent Variable: Keputusan Berkunjung

Berdasarkan Tabel 4.62 diperoleh nilai koefisien korelasi keunggulan bersaing dengan keputusan berkunjung sebesar 0,769. Bila korelasi tersebut diinterpretasikan pada tabel korelasi maka hubungan antara keunggulan bersaing terhadap keputusan berkunjung memiliki hubungan yang kuat sesuai dengan klasifikasi koefisien korelasi menurut Sugiyono (2008:250).

Berdasarkan hasil perhitungan, nilai koefisien determinasi adalah 0,592 atau $59,2 \%$. Hal ini menunjukkan bahwa secara bersama-sama variabel keunggulan bersaing memberikan kontribusi 59,2\% terhadap keputusan berkunjung sedangkan $40,8 \%$ dipengaruhi oleh faktor lain. 
4.3.3 Pengujian Hipotesis dan Uji Signifikansi Secara Simultan (Uji F)

Untuk menguji signifikasi dapat digunakan uji $\mathrm{F}$, untuk lebih jelasnya mengenai output ANOVA dapat dilihat pada Tabel.

TABEL 4.63

\begin{tabular}{|c|c|c|c|c|c|}
\hline \multicolumn{6}{|c|}{$\begin{array}{c}\text { PENGUJIAN HIPOTESIS ,UJI SIGNIFIKANSI } \\
\text { SECARA SIMULTAN } \\
\text { ANOVAb } \\
\end{array}$} \\
\hline Model & $\begin{array}{l}\text { Sum of } \\
\text { Squares }\end{array}$ & $\mathrm{df}$ & $\begin{array}{l}\text { Mean } \\
\text { Square }\end{array}$ & $\mathrm{F}$ & Sig. \\
\hline Regression & 4151,894 & 2 & $\begin{array}{r}2075,94 \\
7\end{array}$ & 70,297 &, $000^{\mathrm{a}}$ \\
\hline Residual & 2864,499 & 97 & 29,531 & & \\
\hline Total & 7016,393 & 99 & & & \\
\hline \multicolumn{6}{|c|}{$\begin{array}{l}\text { a. Predictors: (Constant), Diferensiasi, Keunggulan Biaya } \\
\text { b. Dependent Variable: Keputusan Berkuniung }\end{array}$} \\
\hline
\end{tabular}

*) $\mathrm{F}_{\text {tabel }}=$ df: $100-2-1=2.31$

Berdasarkan Tabel 4.63 diatas, diperoleh nilai $\mathrm{F}_{\text {hitung }}=70,297$ sedangkan $\mathrm{F}_{\text {tabel }}$ dengan derajat kebebasan pada $\alpha(0.05)$ adalah sebesar 2,31 Dengan demikian $F_{\text {hitung }}$ $(70,297)>F_{\text {tabel }}(2,31)$ dengan nilai signifikansinya 0,000 . Nilai signifikansi lebih kecil dari taraf signifikansi 5\%, sehingga jelas $\mathrm{H} 0$ ditolak dan Ha diterima. Dengan nilai signifikansi 0,000 nilai signifikansi lebih kecil dari taraf signifikansi $5 \%$ maka regresi dapat digunakan untuk memprediksi keputusan berkunjung atau variabel keunggulan bersaing berpengaruh terhadap keputusan berkunjung pada taraf kepercayaan $95 \%$. berikut

Hipotesis dalam penelitian ini sebagai

$\mathrm{Ha} \neq 0$, Terdapat pengaruh signifikan keunggulan bersaing berpengaruh terhadap keputusan berkunjung.

Hal ini dapat dibuktikan dengan keunggulan bersaing yang diberikan wisatawan terhadap suatu destinasi diciptakan dari persepsi wisatawan terhadap destinasi melalui perbedaan keunikan dengan pesaing yang menjadikan destinasi tersebut unggul dari pesaing dan merupakan hal yang akan memudahkan wisatawan memiliki asosiasi dengan destinasi tersebut. Hal ini diyakini memiliki kekuatan untuk merubah persepsi dan merubah cara pandang seseorang terhadap suatu tempat atau tujuan termasuk melihat perbedaan sebuah tempat dengan tempat lainnya untuk dipilih sebagai tujuan.

Porter (2008:2), mengungkapakan bahwa alasan utama meneliti keunggulan bersaing adalah untuk membangun sebuah keunikan yang diinginkan yang dapat menarik minat wisatawan, untuk membedakan suatu destinasi dengan pesaingnya dan memposisikan destinasi agar wisatawan melakukan pengeluaran lebih tinggi, untuk mengelola citra, dan membuat sebuah destinasi menjadi tempat yang lebih hidup dengan meningkatkan kontribusi ekonomi melalui pariwisata. Perusahaan yang menjual produk dan kualitas yang sama akan mengalami persaingan yang sangat kompetitif, dengan perusahaan yang telah lebih dahulu berdiri di pasar jika perusahaan tersebut tidak melakukan salah satu dr strategi keunggulan bersaing produk dalam menembus pasar maka akan mudah tergeser sehingga dengan melakukan strategi ini akan mampu menciptakan tingkat kunjungan yang tinggi. 
4.3.4 Pengujian Hipotesis dan Signifikansi

Secara Parsial (Uji t)

TABEL 4.64

HASIL PENGUJIAN SECARA PARSIAL (UJI T)

Coefficients

\begin{tabular}{|c|c|c|c|c|c|c|}
\hline \multirow{2}{*}{\multicolumn{2}{|c|}{ Model }} & \multicolumn{2}{|c|}{ Unstandardized Coefficients } & \multirow{2}{*}{$\begin{array}{c}\begin{array}{c}\text { Standardized } \\
\text { Coefficients }\end{array} \\
\text { Beta }\end{array}$} & \multirow[b]{2}{*}{$\mathrm{T}$} & \multirow[b]{2}{*}{ Sig. } \\
\hline & & B & Std. Error & & & \\
\hline \multirow[t]{4}{*}{1} & (Constant) & 7,896 & 4,269 & & 1,849 & 067 \\
\hline & (X1)Keunggulan & 193 & ,118 & 157 & 1,639 & ,104 \\
\hline & Biaya & & & & & \\
\hline & (X2)Diferensiasi & 453 & ,067 & 646 & 6,734 & ,000 \\
\hline
\end{tabular}

a. Dependent Variable: Keputusan Berkunjung

*) $\mathrm{t}_{\text {table }=} \mathrm{df:} 100-2-1=1,67$

Untuk menguji dimensi dari variable keunggulan bersaing maka dapat digunakan distribusi t-hitung, dapat dijelaskan sebagai berikut:

1. Hasil uji t parsial dapat diketahui bahwa nilai t hitung untuk dimensi keunggulan biaya (X1) sebesar 1,639>1,67, ini berarti bahwa terdapat pengaruh yang signifikan antara dimensi keunggulan biaya dengan keputusan berkunjung.

2. Hasil uji t parsial dapat diketahui bahwa nilai $\mathrm{T}$ hitung untuk dimensi diferensiasi (X2) sebesar 6,734>1,67, ini berarti bahwa terdapat pengaruh yang signifikan antara dimensi diferensiasi dengan keputusan berkunjung.

\subsubsection{Model Persamaan Regresi Pengaruh Keunggulan Bersaing Terhadap Keputusan Berkunjung}

\subsubsection{Hasil Uji Asumsi Sub Variabel}

Pengujian hipotesis ditujukan untuk menguji besarnya pengaruh Keunggulan Bersaing (X) yang terdiri dari Keunggulan Biaya (X1) dan Diferensiasi (X2) terhadap Keputusan Berkunjung (Y). Tabel 4.64 berikut merupakan hasil korelasi antara keunggulan bersaing dengan keputusan berkunjung:

TABEL 4.65

MATRIKS KORELASI ANTAR SUB VARIABEL

\begin{tabular}{|l|l|}
\hline \multicolumn{2}{|c|}{ Y } \\
\hline Y & 1.000 \\
\hline X1 & 0,633 \\
\hline X2 & 0,762 \\
\hline
\end{tabular}

Sumber : Pengolahan Data, 2010

Berdasarkan hasil korelasi matriks antara sub variabel keunggulan bersaing dengan keputusan berkunjung, diperoleh hasil korelasi yaitu, keunggulan biaya $(0,633)$ dan diferensiasi $(0,762)$. Diferensiasi memperoleh koefisien korelasi terbesar, hal ini menujukan bahwa antara diferensiasi dengan keputusan berkunjung memiliki hubungan yang kuat dibandingkan dengan keunggulan biaya. Secara lengkap pengaruh masing-masing keunggulan bersaing terhadap keputusan berkunjung, ditampilkan dalam Gambar 4.15 berikut:

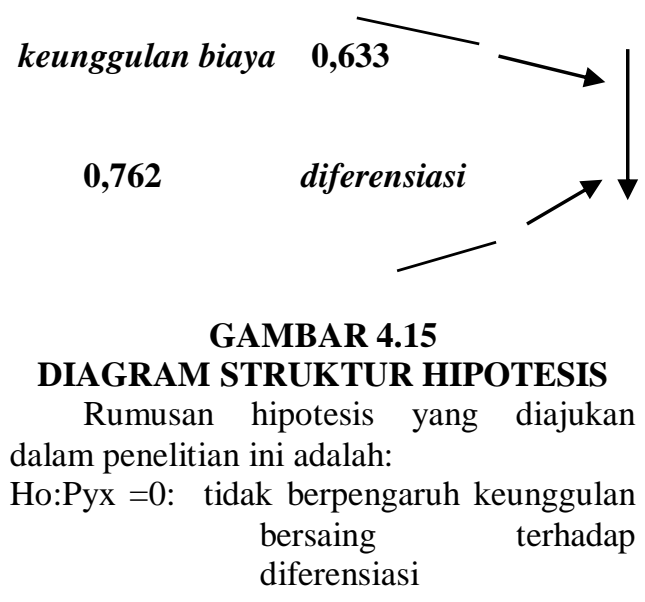

Tourism and Hospitality Essentials Journal (THE Journal), Vol. III, No.1, 2013 - 501 
H1:Pyx $\neq 0$ : terdapat pengaruh keunggulan bersaing terhadap diferensiasi

Dari hasil perhitungan dengan menggunakan SPSS 17, sebagai berikut:

1. Koefisien korelasi antara keunggulan biaya (X1) dengan keputusan berkunjung $\mathrm{r}=0,633$, ini berarti terdapat hubungan yang rendah antara keunggulan biaya dengan keputusan berkunjung. Jika diinterpretasikan korelasi keunggulan biaya dengan keputusan berkunjung adalah rendah dan arahnya positif ini berarti apabila keunggulan biaya baik maka keputusan berkunjung akan meningkat.

2. Koefisien korelasi antara diferensiasi (X2) dengan keputusan berkunjung $r=$ 0,762 ini berarti terdapat hubungan yang tinggi antara diferensiasi dengan keputusan berkunjung. Jika diinterpretasikan korelasi diferensiasi dengan keputusan berkunjung adalah tinggi dan arahnya positif ini berarti apabila diferensiasi baik maka keputusan berkunjung akan meningkat.

\subsection{Pembahasan Hasil Penelitian}

Hasil pengujian hipotesis menunjukan bahwa keunggulan bersaing memiliki pengaruh yang significant terhadap keputusan berkunjung yaitu dengan nilai korelasi sebesar 0,769 yang artinya menunjukan tingkat korelasi yang kuat. Sementara besarnya pengaruh keunggulan bersaing terhadap keputusan berkunjung adalah 52,90\%.

Persamaan regresi yaitu:

$\mathrm{Y}=\mathbf{7 , 8 9 6}+\mathbf{0 . 1 9 3}(\mathrm{X} 1)+\mathbf{0 . 4 5 3}(\mathrm{X} 2)$

Hasil pengujian hipotesis menunjukan bahwa setiap dimensi dari keunggulan bersaing menunjukkan hasil yang positif yaitu:

1. Jika keunggulan biaya dinaikan sebesar satu-satuan maka keputusan berkunjung akan meningkat sebesar 0,193, artinya keunggulan biaya memberikan pengaruh yang rendah terhadap keputusan berkunjung di Taman Air Sabda Alam sebesar 19,3\%.

2. Jika diferensiasi dinaikan sebesar satusatuan maka keputusan berkunjung akan meningkat sebesar 0,453, artinya keputusan berkunjung memberikan pengaruh yang tinggi terhadap keputusan berkunjung di Taman Air Sabda Alam sebesar 45,3\%.
Berdasarkan hasil penelitian ini dapat disimpulkan bahwa keunggulan bersaing memiliki pengaruh yang signifikan yaitu dengan tingkat signifikan 0,000 nilai signifikansi lebih kecil dari taraf signifikansi 5\% maka keputusan berkunjung di Taman Air Sabda Alam dapat dipengaruhi melalui keunggulan bersaing dengan taraf kepercayaan sebesar $95 \%$.

Setiap indikator keunggulan bersaing yang diteliti menunjukan bahwa indikator keunggulan biaya memberikan pengaruh yang rendah, sedangkan diferensiasi memberikan pengaruh yang kuat.

Hasil analisis regresi di atas memberikan hasil adanya pengaruh antara keunggulan bersaing dengan keputusan berkunjung di Taman Air Sabda Alam yang memberikan penjelasan sebagai berikut:

Pengaruh keunggulan bersaing dengan keputusan berkunjung di Taman Air Sabda Alam pada uji t menunjukkan bahwa:

1. Hasil uji $t$ parsial dapat diketahui bahwa nilai $\mathrm{T}$ hitung untuk dimensi keunggulan biaya (X1) sebesar 1,639>1,98, ini berarti bahwa tidak terdapat pengaruh yang signifikan antara dimensi keunggulan biaya dengan keputusan berkunjung.

2. Hasil uji $t$ parsial dapat diketahui bahwa nilai $\mathrm{T}$ hitung untuk dimensi diferensiasi (X2) sebesar 6,734>1,98, ini berarti bahwa terdapat pengaruh yang signifikan antara dimensi diferensiasi dengan keputusan berkunjung.

Hasil analisis pengaruh keunggulan bersaing dengan keputusan berkunjung di Taman Air Sabda Alam berdasarkan uji f menunjukkan bahwa variabel bebas tersebut berpengaruh signifikan terhadap keputusan berkunjung di Taman Air Sabda Alam. Hal ini ditunjukkan oleh Fhitung $>$ Ftabel dengan derajat bebas pembilang dua dan penyebut 100 menunjukkan bahwa nilai sig $(0,000)$ lebih kecil dari taraf nyata $5 \%$ atau $\mathrm{F}$ hitung >Ftabel $(70,297>3,39)$. Sehingga terdapat pengaruh yang signifikan (bermakna) antara variabel keunggulan bersaing dengan keputusan berkunjung.

Berdasarkan hasil perhitungan, nilai koefisien determinasi adalah 0,769 atau $76,9 \%$. Hal ini menunjukkan bahwa secara bersama-sama variabel keunggulan bersaing memberikan kontribusi $76,9 \%$ terhadap keputusan berkunjung. 


\section{KESIMPULAN DAN}

\section{REKOMENDASI}

\subsection{Kesimpulan}

Berdasarkan kajian teori, hasil penelitian, dan pengujian regresi yang dilaksanakan, mengenai pengaruh keunggulan bersaing terhadap keputusan berkunjung di Taman Air Sabda Alam dapat disimpulkan sebagai berikut:

1. Sebagian besar pengunjung menyatakan bahwa pelaksanaan keunggulan bersaing di Taman Air Sabda Alam yang terdiri dari keungulan biaya dan diferensiasi telah dilaksanakan dengan cukup. Dari indikator tersebut diferensiasi memiliki penilaian skor tertinggi dan skor terendah adalah keunggulan biaya.

2. Penilaian menurut sebagian besar responden berdasarkan tingkat kunjungan di Taman Air Sabda Alam yang mendapat penilaian skor rata-rata tertinggi adalah berdasarkan pilihan waktu kunjungan. Sedangkan penilaian terendah adalah pada pemilihan merek.

3. Berdasarkan pengujian hipotesis menunjukkan keunggulan bersaing memiliki pengaruh yang signifikan terhadap tingkat kunjungan di Taman Air Sabda Alam

\section{DAFTAR PUSTAKA}

Ali Hasan. (2009). Edisi Baru Marketing. Yogyakarta: Media Pressindo

Buchari, Alma. (2009). Manajemen Pemasaran dan Pemasaran Jasa. Alfabeta, Bandung.

Cravens, Davids W. and Nigel F. Piercy. (2009). Strategic Marketing. Singapore: Mc. Graw Hill

Fandy Tjiptono, dkk. 2008. Pemasaran Strategik. Andi. Yogyakarta. 2009. Manajemen Jasa.

Andi. Yogyakarta.

Harun Al-Rasyid, "Teknik Penarikan Sampel dan Penyusunan Skala," Bandung: Program Studi Ilmu Sosial Bidang Kajian Utama Sosiologi Antropologi Program Pasca Sarjana UNPAD. 1994

Hermawan Kartajaya. 2010. Brand Operation Bandung. PT Essensi Erlangga Group Bandung.
Human Resources Development PT. Danau Dariza. 2010. Garut.

Husein Umar, 2009. Metode Riset Bisnis, PT Gramedia Pustaka Utama, Jakarta.

Kotler, Philip and Amstrong, Gary. (2008). Principles of Marketing $12^{\text {th }}$ edition. New Jersey: Prentice Hall

(2009).

Principles of Marketing $13^{\text {th }}$ edition. New Jersey: Prentice Hall

(2009).

Manajemen Pemasaran Edisi 13 Jilid Jakarta: Erlangga

Kotler, Philip dan Kevin Lane Keller. (2008). Marketing Management $12^{\text {th }}$ edition. USA: Prentice Hall

(2009). Marketing Management $13^{\text {th }}$ edition. USA: Prentice Hall

Lovelock, Chirstoper, Wirtz J., and Chew P. (2009). Essentials of Services Marketing. Singapore: Prentice Hall

Lupiyoadi, Rambat dan A. Hamdani. (2008). Manajemen Pemasaran Jasa Edisi 2. Jakarta: Salemba Empat

Moh. Ali. (1995). Penelitian Pendidikan, Prosedur dan Strategi. Bandung: Angkasa

Malhotra, Nareshk. (2005). Marketing Research and Applied Orientation. $4^{\text {th }}$ Ed. Prentice Hall Intl., Inc.

Marketing PT Sabda Alam. 2011. Garut.

Pendit, S. Nyoman. (2003). Ilmu Pariwisata. Jakarta: Pradnya Paramita.

Pitana, I Gde dan I Ketut Surya Diart. (2009). Pengantar Ilmu Pariwisata. Yogyakarta: Andi Offset.s

Porter, Michael E. 2008. Competitive Advantage. Karisma Publishing Group Tangerang.

Riduwan \& Akdon, (2006). Rumus \& Data Dalam Aplikasi Statistika. Bandung: Alfabeta, Bandung. 
Rivkin, Steven \& Trout, Jack. 2009. Differentiate or Die. Erlangga. Jakarta.

Schiffman, L.G and Kanuk, L.L. (2007). Consumer Behavior $9^{\text {th }}$ edition. Pearson International Edition

Suharsimi Arikunto. (2009). Prosedur Penelitian Suatu Pendekatan Praktis, Yogyakarta: Bina Aksara.

Sugiyono. (2008).Statistika Untuk Penelitian. Bandung: Alfabeta.

, (2009). Metode Penelitian Kuantitatif, Kualitatif dan $R \& B$, Bandung: CV Alfabeta.

Ulber Silalahi. (2009). Metode Penelitian Sosial, PT Refika Aditama, Bandung.

Wahid Sulaiman, (2004),

Analisis-Analisis Regresi menggunakan SPSS, Yogyakarta : ANDI.

Wheelen, Thomas L \& Hunger, David J. 2009. Manajemen Strategis. ANDI. Yogyakarta.

Riduan. 2005. Dasar-Dasar Statistika. Bandung. Alfabeta.

Suliyanto. 2005. Analisis Data Dalam Aplikasi Pemasaran. Ghalia Indonesia : Bogor

Website :

<http://www.garut.go.id <http://www.tamanairsabdaalamh otel\&resort.com

<http://www.bps.go.id/tourism

<http://www. budpar.go.idhttp://www.west javaindonesia.com/statistic/pertu mbuhan_kunjungan_obyek_wisnu s.html

Dokumen :

Undang-undang Kepariwisataan R.I 2009. http://www.google.com. Accessed 2009 June 8

Skripsi \& Thesis:

R. Reinarsyah Iskandar. (2000). Sinergitas hubungan stakeholder utama pariwisata dan pengaruhnya terhadap keunggulan bersaing di objek wisata pantai pangandaran dalam meningkatkan jumlah kunjungan

Akan, Obasi et al. (2006). Critical Tactics for Implementing Porter's Generic Strategis, Journal of Business Strategy, Vol. 27, no. 1, 45-49.

Yusak Anshori. (2002). Analisis Keunggulan Bersaing Melalui Penerapan Knowledge management dan KnowledgeBased Strategy di Surabaya Plaza Hotel. Jurnal manajemen perhotelan, Fakultas ekonomi universitas Kristen Petra

Sucherly. (2007). Strategi Pemasaran Dalam Meningkatkan Keunggulan Bersaing Serta Implikasinya pada Loyalitas Pelanggan. Jurnal Trikonmika Fakultas Ekonomi Unpa 